\title{
On the capitalization and cultivation of social capital: Towards a neo-capital general science?
}

\author{
Christian Waldstrøm ${ }^{\mathrm{a}, *}$, Gunnar Lind Haase Svendsen ${ }^{\mathrm{b}}$ \\ a Department of Management, Aarhus School of Business, University of Aarhus, Haslegaardsvej 10, \\ DK-8210 Aarhus V, Denmark \\ ${ }^{\mathrm{b}}$ The Danish Institute of Rural Research and Development, University of Southern Denmark, Denmark
}

Received 31 August 2006; received in revised form 16 May 2007; accepted 20 June 2007

\begin{abstract}
Bourdieu's [Bourdieu, P., 1986. The Forms of Capital. In: Richardson, J.G. (Ed.), Handbook of Theory and Research for the Sociology of Education. Greenwood Press, New York, pp. 241-258] seminal definition of social capital as "the aggregate of the actual or potential resources" is reflected in older definitions, as well as in many current within sociology, e.g. [Portes, A., 2000. The two meanings of social capital. Sociological Forum 15 (1), 1-12] and organization [Adler, P., Kwon, S.-W., 2002. Social capital: prospects for a new concept. Academy of Management Journal 27 (1), 17-40]. The definition is interesting, because it directs a dual focus on social capital as both immediately and potentially productive resources, i.e., assets that can be immediately capitalized by individuals as well as 'cultivated' for future use. We argue that to further operationalize this concept we must distinguish between actual/potential social capital, within a neo-capital framework that unifies the existing 'plethora' of capitals.
\end{abstract}

() 2007 Elsevier Inc. All rights reserved.

JEL classification: $\mathrm{P} 00 ; \mathrm{Z} 13$

Keywords: Capital; Social capital; Tangible and intangible forms of capital; Capital taxonomy; Bourdieuconomics

\section{Introduction}

Bourdieu's seminal definition of social capital as "the aggregate of the actual or potential resources which are linked to possession of a durable network" (Bourdieu, 1986, pp. 248-249) builds both on older definitions of social capital ${ }^{1}$ (e.g. Hanifan, 1916; Hannertz, 1969), and is

\footnotetext{
* Corresponding author. Tel.: +45894866 06; fax: +4589486125.

E-mail address: cwa@asb.dk (C. Waldstrøm).

${ }^{1}$ For an overview of early use of the term social capital, see Borgatti (1998), Halpern (2005).
} 
reflected in many current definitions within sociology (e.g. Portes, 1998, 2000) and organizational theory (see Adler and Kwon, 2002 for a review). In contrast to traditional macro economic definitions (e.g. Hanifan, 1916; Hannertz, 1969), this micro level oriented definition brings focus onto social capital as possibly consisting of a sum of actual and potential resources for the individual. $^{2}$

Distinguishing between the two types of social capital (actual/potential) contributes to opening up a range of new possibilities within current social capital research, including the important question of a clear linkage between the individual actor at the micro level and groups and populations at meso and macro levels. It is often argued that social capital does not belong to the single individual in that it exists between people (Lesser, 2000), but it is arguably individuals who create and subsequently profit from social capital. Therefore, as Bourdieu indicated, we cannot simply let out the individual actor in our eager to measure how groups, or whole nations for that sake, profit from a social capital. In other words, the social capital of a single person is concrete and possibly measurable, whereas social capital that presumably belongs to groups or whole nations often appear as mere abstractions when the micro-sociological level is cut out (cf. Portes, 2000).

In the literature, it is generally agreed upon that individuals as well as groups can obtain future gains, which more or less directly derive from their personal networks, that is, their social history in the form of concrete, personal relationships. Moreover, today it appears evident, also among many economists, that social and economic dimensions of networking can only be separated in a highly artificial way. Thus, the concept of social capital seems to be born with skepticism towards reductionist economic 'laws of nature'. This distinction has been thoroughly discussed by Granovetter (1985), who specifically challenges over- and under-socialized theories of human action.

Nevertheless, in the following we argue that the Bourdieusian 'potentiality' argument has been underestimated in current social capital literature. This is due to lack of attention to, and systematically distinguishing between, the two types of social capital. This relates to more fundamental questions, such as: What is capital, and how is it used? And which forms of capital exist? Understanding the difference between actual and potential social capital frames the question differently: How does social capital work as both an end in itself and a means to reach other ends?

Thus, the purpose of this paper is two-fold.

First, to define the two types of social capital within a neo-capital theory framework. That is, types which differ in crucial ways, in that the first one can be seen as the outcome of immediate socioeconomic practice; while the other reflects more complex, long-term strategies characterized by a structural unpredictability that challenges actors' capability of cultivating social networks within a 'cultural game'. Such sociologically oriented findings have wider implications for the social capital agenda, by pointing out two main areas for future research - actually capitalized and potential social capital - urging social capital researchers to apply both quantitative and qualitative methodologies.

Second, our aim is to further develop a neo-capital theory, which critically evaluates and links the traditional forms of capital with a still growing number of more or less exotic forms of capital in contemporary literature, ranging from digital to religious, social, cultural and organizational capital. We argue that such reorientation leads to a new socioeconomics operating with both visible and invisible forms of capital at the same level in the analysis, thus bridging the gap between economic and socio-cultural studies.

\footnotetext{
${ }^{2}$ A special thank to one anonymous reviewer for valuable suggestions.
} 
In Sections 2.1 and 2.2 we summarize the critique of homo oeconomicus, which seems to have led to the concept of social capital in the first place. Furthermore, we explore 'capital' and 'social capital' definitions within classical and neo-capital theory. In Section 2.3 we review problems within contemporary social capital research. In Section 3 we argue that these problems can partially be resolved by implementing the actual/potential distinction in future research. This within a broader neo-capital research agenda, termed Bourdieuconomics, and drawing on a capital test model, PIPES - in order to unify the existing 'plethora of capitals' (Baron and Hannan, 1994, p. 1122) within one, neo-capital theoretical framework. Finally, in Section 4 we apply this theoretical approach to a Danish case.

\section{Theoretical framework}

Portes (2000, p. 1) states that social capital is "arguably one of the most successful "exports" from sociology to other social sciences and to public discourse during the last two decades". This interest has stimulated "a vast output of theory and research" (Kadushin, 2004, p. 88), and academic cross-fertilization has created an interesting but very diverse field, leaving a number of unresolved issues. After a short review of the definitions of capital, we will present the main points of critique that have been raised, some of them raising doubts about whether social capital can be considered as a capital at all. These include lack of conceptual precision, problems with causality relations and measurement, lack of a definition of negative types of social capital and a systematic distinguishing between micro and macro levels. Next, we will argue that an actual/potential resource perspective within a neo-capital theoretical framework can help us to overcome some of these problems.

\subsection{What is capital?}

\subsubsection{Classical and neo-capitalist definitions}

Social capital has been criticized for being neither social (Roberts, 2004), nor capital (Robison et al., 2002). For example, Kenneth Arrow (2000, p. 3) cuts to the bone when stating that motives for interacting cannot be seen as intrinsically economic. The interaction in itself "is the reward". He admits that networks may serve for economic purposes, e.g. in connection with job seeking. However, most people do not join networks to fulfill narrow economic purposes but, simply, for social (non-economic) reasons. Following Arrow, 'capital' is constituted by three elements: "(a) extension in time; (b) deliberate sacrifice in the present for future benefit; and (c) alienability". Not least, 'social' capital fails to be an investment of human time and resources for future benefit, in that "[the] essence of social networks is that they are built up for reasons other than their economic value to the participants" (op.cit., p. 4). Similarly, Solow (2000, p. 6) sees social capital as "a bad analogy". How can intangible forms of capital exist, when the term 'capital' originally means a physical stock of production factors? He asks rhetorically. And if they do: How on earth can they be measured? Like Arrow, he does not deny the economic importance of social networks - but why not avoid the metaphor and call things for what they really are? - namely 'patterns of behavior' and 'social norms': "The story gets more interesting when it has to allow for the fact that a lot of economically relevant behavior is socially determined" (op.cit., p. 8).

In sum, the adoption of social capital into the popular areas of research has given the term a somewhat loose and metaphorical use. It is therefore our clear belief that if social capital is to continue to gain status as an academic term, it is necessary to critically assess its status as a capital. 
Within the human sciences, the historical development of forms of capital has shown an increasingly shortening time-to-market. Since the work of Marx in 1848 describing 'capital' in a systematical way for the first time (Marx, 1995), some time went by, before the term 'human capital' surfaced a little more than a century later in the form we know it today (Becker, 1964; Schultz, 1961). Then, only a decade later, Bourdieu (1989) presented the theories of 'cultural capital' as a political resource for the elite.

In this context, Lin (1999, p. 29 ff.) proposes a useful distinction between Marx' classical theory of capital, i.e., a theory based on the "exploitative social relations between two classes" and neo-capitalist theories including the human, cultural and social capital theories of Becker, Bourdieu, Coleman and Putnam. Whereas the Marxian capital theory is structural and primarily focused on zero sum games (capital as a surplus value appropriated by capitalists), the neo-capital approach is prevailingly directed towards individual and group levels and - in contrast to Marxian thinking - it takes social mobility and plus sum games into consideration.

Just as the invention of human capital acted as a kind of kick-starter for cross-disciplinary research during the 1960s (Becker, 1964; Schultz, 1961), social capital has led to a common research interest within the human sciences around the turn of the new millennium. So we see that the family of neo-capitalist theories is rapidly growing, among them the social capital research agenda rooted in a Durkheimian social order approach prevailingly, even if Bourdieu in a Marxian vein continued to use the concepts of class and class struggles in his analyses. This has, however, blurred the conceptual landscape, leaving us with the abovementioned 'plethora of capitals' which, following (Baron and Hannan, 1994, p. 1123), has given rise to "a minor sociological industry [...] to construct sociological parallels to human capital". As many authors have suggested, it is therefore important to further explore this previously taken-for-granted term, in order to reach an acceptable ground definition of 'capital'.

\subsubsection{Tangibles and intangibles}

In Wealth of Nations, Adam Smith (1976) saw 'capital' as stored up or accumulated labor fixed or 'realized' in visible, tangible objects rendering future revenues, like machines, manufactures, materials, tools and money. Thus, sharply distinguishing between productive and unproductive labor, Smith explained that in contrast to the unproductive, however indispensable 'hands' of e.g. menial servants and the sovereign king ...

the labour of the manufacturer fixes and realizes itself in some particular subject or vendible commodity, which lasts for some time at least after that labour is past. It is, as it were, a certain quantity of labour stocked and stored up to be employed, if necessary, upon some other occasion (Smith, 1976, p. 330).

More recently, economists have operated with real capital (or capital goods) meaning produced production factors in the form of buildings, machines, tools, land and infrastructure, while financial capital consists in liquid assets, stocks, bonds, etc., which are invested in real capital (Robison et al., 2002; Svendsen and Svendsen, 2003). More broadly, economists talk about investments in the form of saved consumption that can be used in the future, that is, in line with the classical definitions (Arrow, 2000; Robison, 1996).

With a specific focus on social marginalization, economist Ivan Light (2001, p. 1) defines capital as "any store of value that facilitates action". He traces the concept back to 19th century economists, including Marx, at a time when "financial and physical capital were the only forms of capital" (Light, 2001, p. 1). He adds three more recent forms of capital, namely human, cultural and social. 
These five forms of capital have two properties in common: Storability and metamorphosis, i.e., a capital can transform into any other form of capital (Light, 2001, p. 5). Moreover, the tangible forms of capital - financial and physical - can be taxed by authorities. Finally, Light sees social capital as the only non-excludable good, characterized by "popular access" - in contrast to the four other forms of capital, which "exclude the poor, ignorant, unpropertied, and downtrodden" (ibid, p. 5). In other words, social capital is the only capital that is accessible for - and, thus, can be practically accumulated by - rich and poor alike. This is because investing in it only costs time and energy, not monetary or, one might add, symbolic resources, the latter in the form of e.g. formal titles and occupations.

This does, however, not exclude Lin's (1999, p. 40) important observation that access to more resourceful networks depends on the individual's reputation, material wealth and hierarchical position. This is due to the old truism that you have to be able to offer something to get something in return, that is, being able to reciprocate.

Thus, we see that, in Light's model, only social capital is an asset that facilitates social mobility, that is, a possible metamorphosis of invisible capitals into material wealth available for poor people as well as rich. Consequently, from this perspective one might argue that only this capital form should be seen within what Lin terms a 'neo-capitalist theory' framework.

Bourdieu also envisioned a new socioeconomics termed "a general science of the economy of practices", i.e., a science revealing capital "in all its forms and not only in the one form which is recognized by economic theory" (Bourdieu, 1986, p. 242). Thus, in an early article from 1986, "The forms of Capital", Bourdieu presents an original hypothesis of the existence of material as well as non-material forms of interchangeable capital within specific fields (economic, political, juridical, artistic, religious and scientific). In the article, he defines four forms of capital: Economic, cultural, symbolic and social. However, overall his works reveal that the number of forms of capital - like the number of fields - seems to be unlimited, ranging from economic, cultural, technological, juridical, organizational, commercial, symbolic to social capital (Bourdieu, 1979, 1980, 1986, 1997, 2000). Within the framework of such an extraordinary, anti-economistic neo-capital theory that reflects the economic anthropological findings back to Weber, Simmels, Durkheim, Mauss and Polanyi, he defines social capital as "the aggregate of the actual or potential resources which are linked to possession of a durable network of more or less institutionalized relationships of mutual acquaintance and recognition" (Bourdieu, 1986, p. 248).

So, we see that overall, at the beginning of the 21 st century, we seem to be moving in the direction of a neo-capital theoretical framework. This new framework includes half a dozen forms of capital - tangibles as well as intangibles - and all of which can be transformed into each other, in conformity with specific cultural norms and rules. Such an idea was presented by Bourdieu in his visionary outline of 'A general science of the economy of practice' around 1980 (Bourdieu, 1979, 1980, 1986), why such a new socioeconomics rightly should be termed 'Bourdieuconomics' (Svendsen and Svendsen, 2003).

\subsection{Economy, culture and capital}

\subsubsection{Critique of homo oeconomicus}

Mediating between the words 'social' from the sociological reign and 'capital' from the economic reign, the concept of social capital implies recognition of economic rationality. This does, however, not imply reducibility to a universal rational actor. For certain, the concept contains a critique of orthodox economic thinking, which can be traced back to Durkheim's (1908, p. 5) rejection of the theory of economic materialism, which makes economic life the "underly- 
ing structure" (substructure) of social life; to Polanyi's (1957, p. 3) aversion against the "stark utopia" of a self-adjusting market; or to Bourdieu's (2000) more recent advocacy of an economic anthropology (une anthropologie économique), i.e., an economy with 'social structures' aimed to replace the empirically uncontested idea of homo oeconomicus. In a similar vein, Granovetter (1985) has proposed the term embeddedness in order to contextualize the idea that all economic action is inherently part of a more generic social context.

Note that such scholars do not reject that social relationships can be utilized as an economic resource in the here and now. But they do reject the idea that people always should be able to plan and carry out strategies in a strict (economically) rational way. Strategies are embedded in complex cultural 'games' and their future outcomes therefore unpredictable to a higher or lesser extent. Bourdieu realized this early on, and it seems to be the main reason why he did not continue his close cooperation with French econometrics during the 1950s (Lebaron, 2003).

\subsubsection{Veblen and Bourdieu}

Bourdieu's second key idea in 'A general science of the economy of practice' - the suggestion of tangible and intangible assets that can be converted into each other - can also be traced back in theory history. Thus, an important, early critique of neo-classic definitions of capital is American sociologist and economist Thorstein Veblen's (1908a) harsh critique of Fisher's capital theory i.e., a theory, which only includes visible, financial and physical assets. However, when tangible forms of capital are equally distributed among enterprises, how do we explain evident differential advantages among them? Exactly, answers Veblen, by including more intangible assets in the analysis (Veblen, 1908a, p. 2). ${ }^{3}$

Veblen points out that Fisher's taxonomic and unempirical Austrian economics suffers from the failure of a "normalized scheme of economic life" in which "wasteful, disserviceable, or futile acts have no place". The failure roots in a "habitual refusal of economists to recognize intangible assets" in their definitions of the term 'capital':

As a correction of current usage the attempted exclusion of intangible assets from "capital" does not seem a wise innovation. It cripples the definition for the purposes which alone would make a definition worth while (.) The habit and the necessity of taking account, under one name or another, of the various immaterial items of wealth classed as intangible assets counts for more and more in the conduct of affairs (Veblen, 1908a, p. 2).

The shortcomings of a definition of capital excluding intangible assets (Veblen, 1908a,b,c) also form a starting point for Bourdieu's neo-capital socioeconomics (Bourdieu, 1986). Here, the revolution consists in placing invisible non-material assets at the same level in the analysis as those recognized by orthodox economics (Bourdieu, 1986, p. 243). This is simply done by naming them social, cultural and symbolic capitals (Anheier et al., 1995, pp. 862-863; Mahar et al., 1991, pp. 13-14; Svendsen and Svendsen, 2004, p. 16ff).

Taking Veblen's and Bourdieu's critique in mind, it might surprise that the idea of intangible, non-material forms of capital is not incompatible with the classical ground definition of capital as human labor that has been accumulated through history. Apart from Adam Smith and other liberal economists, this definition was also applied by Marx who spoke about 'heaped up labor' (aufgehäufte Arbeit) and 'stored up labor' (aufgespeicherte Arbeit).

\footnotetext{
${ }^{3}$ A tangible/less tangible resource approach has also become popular within regional economics, including Differential Economic Performance (DEP) studies in peripheral rural areas (see Bryden and Munro, 2000).
} 
Also Bourdieu (1986, p. 241) defines capital broadly as: "accumulated, human labour," which can potentially produce different forms of profits. The Bourdieusian revolution is to follow this logic to its end by stating that accumulated human history is transferred through time in both things and human beings, that is, in objectified - i.e., material - form, as well as in embodied form, i.e., as part of a person:

Capital is accumulated labour (in its materialised form or its "incorporated", embodied form), which, when appropriated on a private, i.e., exclusive, basis by agents or groups of agents, enables them to appropriate social energy in the form of reified or living labour (Bourdieu, 1986, p. 241).

\subsection{3. $M$-world versus $R$-world models}

The social capital agenda implies exactly such a perspective on economies as open systems, the outcomes of which cannot be computed mathematically in any accurate way. This view has partly been recognized by economists themselves, e.g. in a recent dispute on economic formalism in The Economic Journal (Chick, 1998; Krugman, 1998; Weintraub, 1998). For example, Backhouse (1998, p. 1852) refutes excessive economic formalism by stating: "Axiomatic methods are an appropriate way to find out about the properties of M-World [worlds of models and concepts] models, but economics is about the truth of propositions concerning R-World [real world] phenomena".

The distinction between abstract model world and real world models appears crucial when talking about investment in, and capitalization of, social capital. Thus, whether an attempt to capitalize social capital will turn out a success or a failure seems fairly predictable in the here and now. This lies somewhat in the frame of the widely used definition presented by Lin (1999, p. 30): "Investment and use of embedded resources in social relations for expected returns".

Say, for example, you ask some friends to help you move next month. The probability of success will be high. However, investment in social capital with the hope of future capitalization tends to be a more risky and unpredictable business. That is, the further capitalization is pushed into the future, the more risky the investment - much like weather forecasts. At this point, human practice becomes less predictable and less 'rational' for econometrists - but not for sociologists or anthropologists, who are used to deal with long-term individual or group strategies in cultural games, which can never be entirely reduced to economic rationality. Say, you ask some friends or acquaintances to do you a favor, for example help you to get a job - or move next month - you might ripe the fruits of such relationships. But would they do the same thing if you needed the new job, or to move to a new house, in ten years time or so? Maybe not. But your best friends and close family probably would.

This indicates that investments in strong ties are often less risky and more predictable than investments in weak ties. On the other hand, and as was first shown by Granovetter (1973), investments in weak ties in the form of colleagues and acquaintances with other backgrounds and networks than yourself often tend to be more profitable when capitalized e.g., in order to get a new job. This links to current discussions of trust and social capital (e.g. Herreros, 2004; Pollitt, 2002; Uslaner, 2002) and the distinction between bridging and bonding types of social capital (Putnam, 2000; Svendsen and Svendsen, 2004).

\subsubsection{Is social capital a capital?}

Social capital shares some properties with other forms of capital, but it is different on a number of properties (Robison et al., 2002). Others, like Halpern (2005, p. ix) argue 


\section{Methodology Level \\ QUALITATIVE}

Bourdieu (1986)
"the aggregate of the actual or potential resources which are linked to
possession of a durable network of more or less institutionalized
relationships of mutual acquaintance and recognition"
Focus: power relations, concrete networks, reasonable strategies,
individual benefits
Coleman (1990)
"Like other forms of capital, social capital is productive, making
possible the achievement of certain ends that would not be
attainable in its absence".
Focus: socialization, families, rational actor strategies,
societal benefits
Putnam (1993)
"networks, norms, and trust that facilitate co-ordination and co-
operation for mutual benefit"
Focus: civic traditions, political systems, societal benefits

Fig. 1. Three famous social capital definitions.

that social capital is not necessarily the best term, but might just as well be called 'social fabric'.

There have been many definitions of this new, presumed capital form. They range from definitions directed towards qualitative analyses at the micro level to statistical surveys at meso and macro levels, involving completely different foci - illustrated by the famous definitions of Bourdieu, Coleman and Putnam (Fig. 1).

However, not seldom have these definitions suffered from lack of precision (Herreros, 2004), e.g. Putnam's much criticized 1993 definition: "networks, norms and trust". But does social capital consist of networks or norms or trust?

Thus, is it necessary to return to the question of what constitutes a 'capital'? And to which extent does social capital share properties with other types of capital, such as old capitals such as physical and economic capital and the more recent human capital? Does it have capital-like properties such as transferability, durability, flexibility, substitutability, maintenance, investment, etc. (Robison et al., 2002)? In the discussion of social capital it is often an underlying assumption that social capital is sought after because of the benefits derived thereof and that influence in social networks can entail financial benefits and vice versa. 
Let us now take a look at the main criticisms and on that background evaluate, if there is indeed 'fire behind the smoke' (Paldam and Svendsen, 2000) when examining this both promising and problematic concept.

\subsubsection{Causality}

Lack of clear causality relations has been a general problem within analyses of social networks (Borgatti and Foster, 2003) including social capital research (Waldstrøm, 2003). Not least Putnam has been accused of unclear causal connections, especially of confusing cause and effect. The dispute culminated in the spring of 1996 in a quite emotional debate in The American Prospect (Portes and Landolt, 1996; Putnam, 1996; Schudson, 1996; Skocpol, 1996). The critique can be summed up in Portes' and Landolt's rejection of Putnam's one-dimensional view of social capital as something always positive, civil(ized), democratic and commonly good, while the opposite corruption, distrust, familism, etc. like in Southern Italy (Putnam, 1995) - simply is identified as lack of social capital.

The one-sided picture of social capital produces a series of tautologies, truisms, and stereotypes (Lin, 2001). At the collective level, a tautology occurs when the success or failure of a particular community is identified a posteriori with the presence or absence of social trust or social capital. In the celebratory view of social capital, if an agricultural cooperative advances economically or a city effectively carries out a reform program, it is because they had high levels of social capital to begin with; if they fail, they did not. This circularity of reasoning is facilitated by the identification of the same traits as determinants and consequences (Portes, 1998; Portes and Landolt, 1996).

With the derived benefits of social capital represented in different areas of research as both indicators, results, and proxies, the inevitable result is problems in measurement (Lin, 2001). However, the solution to the problem of causality lies in the understanding of the actual and potential parts of social capital, since this opens for the clarification of the direct and derived benefits from social capital, as will be developed below.

\subsubsection{Measurement}

It is partly due to lack of clear definitions that there have also been problems with operationalization and measurement on the one hand, and causality on the other. For example, Solow questions the investment aspect of social capital in the following instructive way, which seems to sum up the reservations of the skeptics:

Just what is social capital a stock of? Any stock of capital is a cumulation of past flows of investment, with past flows of depreciation netted out. What are those past investments in social capital? How could an accountant measure them and cumulate them in principle? (Solow, 2000, p. 7).

Classifying social capital as leading to either positive or negative outcomes has made it possible to apply more precise proxies for stocks of social capital and their impact on economies (Beugelsdijk and Smulders, 2004; Patulny, 2003) and social capital of individuals (Täube, 2004). ${ }^{4}$ However, problems with measurement are evidently not only a question about statis-

\footnotetext{
${ }^{4}$ Due to lack of space, we will not here go into the interesting discussion about externalities (Cornes and Sandler, 1986). However, we may assume that, concerning investment in social capital, both positive and negative outcomes - or externalities - are unintentional. This simply means that agents are not aware of the societal benefits, or evils, their actions involve. This links to Coleman's (1990) famous idea that social capital is created as a by-product, that is, unintentionally (see also Herreros, 2004).
} 
tics and econometrics. We would rather argue that the root of the problem lies in two major, methodological deficiencies: the lack of a clear definition of capital and of a capital theoretical framework, and a lack of qualitative methods that would enable descriptions and analyses of concrete processes of building positive and negative types of social capital (Svendsen, 2006). The latter would allow us to bridge the gap between formal rules and actual strategies (Bourdieu, 1977).

Moreover, historical perspectives are absent, not least in the many quantitative studies. This might surprise when considering that a capital consists of accumulated, historical work transmitted in things and people. The trend seems to be that many academics seek to measure social capital effects post facto. However, they forget that social capital is created by living people in situ, that is, in specific historical processes as well as in the here and now. A combination and crossfertilization of quantitative and qualitative methodologies might be a solution (Chloupkova et al., 2003; Svendsen and Svendsen, 2004).

\subsubsection{The downside of social capital}

As was the case in the early phases of the development of social network analysis, social capital theory was initially focused solely on social capital as benefits (Borgatti and Foster, 2003). However, a growing body of research has sketched out some of the negative aspects of social capital.

As has already been discussed, excessively strong ties within a group can threaten the collective good. 'Superglued' groups can even be utterly destructive towards non-members, a problem convincingly exemplified by Coleman (1990), Mingione (1991), Putnam (1993), Uslaner (2002) and, in particular, in anthropological literature (Banfield, 1958; Douglas, 1966; Kapferer, 1988; Keesing, 1992; Tambiah, 1996; Turner, 1967).

Portes points to the complex interaction of positive and negative kinds of social capital, even within the same network - something, which makes social capital hard to measure and complicates identification of clear causality relations. As such, Portes' and Landolt's further development of Bourdieu's seminal definition can be seen as a logical reaction to a, since the beginning of the 1990s, widespread "celebratory view of social capital" (Portes and Landolt, 1996, p. 21), which - promoted by social capital enthusiasts such as Francis Fukuyama and Robert Putnam - tends to underestimate methodological problems.

As mentioned, not least Putnam has been criticized for a narrow approach, often by sociologists. Possibly taking such criticisms into consideration, chapter 22 in Bowling Alone (Putnam, 2000) has been entitled: "The dark side of social capital". The book gives a clear picture of the decline in civic engagement in the United States since the strong civic movements of the 1960s. But we do not find a systematic implementation of bridging/bonding on the empirical data.

Another avenue of research has treated 'social capital' as the positive aspects of social structure, and 'social liability' as the negative aspects thus using accounting terms from classical capital to social capital (Brass and Labianca, 1999; Labianca et al., 1998). Recently, the term 'social capital audit' has even been proposed by Halpern (2005, pp. 31-32).

The issue of the negative aspects of social capital is a continued discussion of the ownership of social capital, since the exclusion of social networks can hardly be termed negative social capital, unless positive and negative externalities are considered. Thus, other people's social structures might benefit or harm third parties through spill-over (generalized) trust or denial of access to resources, necessitating an understanding of how social capital is embedded at the micro and macro level. 


\subsubsection{Social capital at the micro and macro level}

In dividing social capital into "what it is, where it resides, what it produces ... and how produced” (Robison et al., 2002, p. 4), social capital is defined as “a person's or group's sympathy towards another person or group that may produce a potential benefit, advantage, and preferential treatment for another person or group of persons beyond that expected in an exchange relationship" (Robison et al., 2002, p. 4). This reflects a shift from the structural aspects of social networks towards the surplus value provided by affective properties of relations. Thus, the capital metaphor is used, paradoxically, as the unexplained variation in relationships, which are otherwise based on classical economic mechanisms such as transaction costs, cost-benefits, etc.

This seems to be a somewhat unambitious avenue of research, since the full implementation of social capital as more than a metaphor would entail that the affective, trust based and sympathy driven benefits of a relationship are a property of the relationships themselves, possibly even the main reason for the creation and sustainability of the relationship.

It is the implicit assumption of most literature that social capital is not the property of actors, but exists in the social relations of the actor. However, this is not particular to social capital. The value of financial capital can change due to external factors such as inflation, devaluation, or market fluctuations. Human capital will always be valued relative to the context in which the individual is placed - and like financial capital, it can become obsolete due to the depreciation and changes caused by new developments in the environment outside the control of the individuals. While it is true that social capital exists because of the connections between actors and not within the actors themselves, the benefits of social capital will be of benefit to the actors - and possibly the collection of actors in groups or whole organizations.

Thus, even if social capital is not strictly the property of the individual actor, it is necessary to determine the value of the social capital for each individual. It can be argued that social relations only turn into capital, when it is valued by an individual. This will explain the asymmetries in the importance placed in and benefits gained for two actors in a relationship (Portes, 2000). To state the obvious: A relation between two actors is not an entity in itself and therefore it cannot benefit from the social capital.

It is therefore important to make the following distinction: While social capital is the property of actors, the derived benefits of social capital can be either to the single actor or to a group of actors.

The levels of analysis can be subdivided into a number of levels between the individual and the organization (teams, groups, divisions, etc.) (Labianca et al., 1998). The same mechanisms are at play, however, since the unresolved problem of ownership pervades this issue. In stressing the importance of being stringent about the level of analysis in discussing social capital, the effects of interactions between structure and social capital at the micro and macro levels are separated and analyzed in the following.

At the individual level, actors who know the social structures can reap the greatest benefits of the network (Johnson and Orbach, 2002; Krackhardt, 1990). However, it is not clear to what extent they can alter the structure (Krackhardt, 1987; Lin, 2001). Recent literature, however, has introduced the term social capital management, which perceives social capital as an asset that can be actively and consciously accumulated and used by individuals and organizations (Leenders and Gabbay, 1999). In this interesting avenue of research, the idea of corporate social capital is presented as: "The set of resources, tangible or virtual, that accrue to a corporate player through the player's social relationships, facilitating the attainment of goals" (ibid, p. 8). In stressing the importance of being stringent about the level of analysis in discussing social capital, the effects of interactions between structure and social capital at the individual and organizational levels are 
separated and analyzed in the following. Whether using the term corporate social capital (Leana and Van Buren, 1999) or organizational social capital (1998), focus has recently been placed on social capital at the meso level, thus placing an importance in understanding social capital at a level between the micro level of personal social networks and the macro level of society.

At the organizational level, Nahapiet and Ghoshal (1998) argue that social capital is not only a critical resource, but the only factor which can provide decisive and lasting organizational advantages, a point further developed by others (see Bolino et al., 2002; Ibarra, 1992; Lazarsfeld and Merton, 1954; McPherson et al., 2001). Therefore, it is clear that organizations need to be conscious of their social capital, and of the factors necessary to create and nurture it. Since organizations have various degrees of institutionalized culture, norms and values, the cohesiveness necessary for the development of social capital is already present. Since many interpersonal relations are created and developed because of mutual liking and/or homogeneity between individuals (Halpern, 2005, pp. 14-19), social networks will occur in organizations, giving rise to social capital.

At the regional or national level, social capital is used less in connection with specific social networks and more as derived benefits of a general 'social structure'. Therefore, the discussion of ownership of social capital is less relevant since social capital is thought to be a property of a community or region comparable to other sociological indicators such as level of education, norms, health and economic wealth (Lin, 2001).

What is lacking in this analysis is the interaction between the social capital of the individual and the collective social capital of the organization and vice versa, leading to some of the most important gaps in the current theory of social capital in organizations. Therefore, in the following we will propose to reframe the social capital agenda in an actual/potential perspective, and integrated in a Bourdieuconomics, which seeks to explain and unify the existing 'plethora of capitals' within one, coherent neo-capital theoretical framework.

\section{Social capital seen in an actual/potential perspective}

\subsection{Social recognition and the costs of building social capital}

If social capital encompasses also the potential resources in a social network, some degree of awareness of those resources must exist for the focal actor (Carley and Krackhardt, 1996; Krackhardt, 1987). Thus, an interesting parallel exists to the research into cognitive social structures, and the research which shows that not only a particular network structure or position, but also a correct understanding of the network structure, determines one's power or benefits from a network (Krackhardt, 1990). This fact is highlighted by "share some common properties (either perceived by the observer, others or themselves" (Bourdieu, 1980, p. 2), since few properties are strictly objective - even such typical properties as race, gender and age are somewhat subjective in importance and influence.

Both the theory of the strength of weak ties (Granovetter, 1973) and the theory of structural holes (Burt, 1992) are based on the assumption that the benefits of relations go further than just the relations to 'the relations of relations'. Thus, it is important to distinguish between potential resources of contacts (e.g. that an existing contact might be useful in an unforeseen situation) and the potential usefulness of contacts of contacts.

This strongly questions the social capital altruism that cooperative networks are always good for actors, also in the narrow economic sense. Is it always 'profitable' or 'reasonable' to invest time and energy in cultivating networks, even if it does not pay in one way or the other? For 
example, as Kadushin (2004) writes, if you borrow a cup of sugar of a neighbor, it might be relevant for you to ask yourself: What are the costs of borrowing this cup of sugar (e.g. in the form of unwanted reciprocal relations, waste of time, bad conscience, etc.)? Thus, strategies based on social recognition might lead to less 'social capitalism', when an actor perceives that a social capital is useless for him or her and time and energy might be spent in a better way on other things.

Take the example of a Turkish immigrant who owns a garage in the village of one of the authors. One day the author went to him to have his car repaired. While waiting for some spare parts to arrive, there was time to a little chat. The mechanic told that until recently he had had his garage in the nearby city of Århus, which is the second largest city in Denmark, in a part of the city named Brabrand, where many immigrants, including Turks, live. It had been a very busy time there, he assured. "Then why did you move?" the author asked. He then explained in detail how Turkish relatives, friends and acquaintances had visited his garage in Brabrand almost daily, forcing him not only to repair their cars for almost nothing but, even worse, to sit and converse politely. In this way, he was disturbed all the time and could not get his work done. This makes one ask: From the mechanic's point of view, is this a good and profitable network? Socially it might be, but economically - certainly not! It is a social capital that, though cultivated, can only be capitalized with great difficulties, if at all.

Such examples question the truism that trust always lubricates co-operation and stimulates economic growth at micro as well as macro levels. In reality, trust is not always productive for anyone, just as one may doubt if it is always profitable for the individual to invest in social capital. As pointed out by Granovetter (1985) embeddedness and trust might in fact be necessary for malfeasance in economic action.

Again, the conceptual pair of bridging/bonding becomes helpful. However, the lack of a clear definition should nonetheless be seen as a serious problem, or challenge. As a result, applying the concept of social capital sometimes seems to raise ten more questions for each answer.

\subsection{PIPES and Bourdieuconomics}

On the background of the findings and critiques within capital and social capital theory reviewed in Section 2, combined with the distinction between actual/potential resources, it now becomes possible to outline an extended definition of capital within the Bourdieu-Veblen socioeconomic framework. A definition of capital which, in vital ways, reframes the social capital agenda. This we do by introducing our PIPES model. That is a model, which

(1) acknowledges the neo-classic ground definition of capital as a stock of accumulated or 'stored up' human labor, cf. Marx;

(2) takes into consideration the existence of both tangible and intangible forms of capital, cf. Veblen and Bourdieu, and accordingly;

(3) takes into consideration that forms of capital can be transmitted in both things (objectified form) and within human beings (incorporated form), cf. Bourdieu;

(4) analyzes tangible and intangible forms of capital at the same level in the analysis, cf. Bourdieu;

(5) describes and explains how various forms of capital are transformed into each other, cf. Bourdieu and Light;

(6) describes and explains human strategies that can be seen as both reasonable (and thus comparable across cultures and nations) and rooted in cultural practices and norms (that is, specific and embedded); 
Table 1

Properties of capital within an actual/potential resource framework: PIPES

\begin{tabular}{ll}
\hline Actual resource & Potential resource \\
\hline Productive & Prospective \\
Interchangeable & Embedded \\
& Strategic \\
\hline
\end{tabular}

(7) operates within a neo-capital theory framework, cf. Bourdieu and Lin-a framework that may be termed 'Bourdieuconomics', because it seeks to further develop Bourdieu's original vision of 'A general science of the economy of practice' (Svendsen and Svendsen, 2003).

For economists, capitals are characterized by what can be termed PP, i.e., Productiveness (in the here and now) and Prospectiveness (future productiveness due to previous investments). This is in many ways similar to what Bourdieu calls actual and potential resources and what economists, discussing measurement, at times have termed Real-world and Model-world models, as already mentioned.

The PP combines with the convertibility or, in Light's terminology, metamorphosis of one form of capital into another, and the cultural embeddedness of capital and capital transactions (cf. Bourdieu, 1986). Moreover, struggles for, and investments in, various forms of capital imply reasonable human strategies within a cultural game, involving personal profits - although not strictly 'rational' and 'predictable' human practice in the Rational Actor understanding (ibid).

Thus, we end up with a definition of capital as PIPES - Productive, Interchangeable, Prospective, Embedded, and Strategic - where the PI constitute the actual and PES the potential resource of a capital, cf. Table 1 .

\subsection{Capital as an actual resource}

Thus, capital as an 'actual resource' implies that a capital is Productive, which means that it is immediately capitalizable (Table 1). For example, a human capital can be built by an individual (potential resource) and ultimately transformed into a well-paid job and economic capital (actual resource). From this also follows that, with a certain risk, a capital's value can be increased by converting it into other forms of capital (Interchangeable) (Robison et al., 2002, p. 11).

However, that a capital is interchangeable or convertible does not only mean that it can be transformed from one form into another, but also that a capital can shift between many functions, i.e., that it is flexible. For example, a physical capital such as a car can offer transportation as well as carry groceries, pull trailers and provide a shelter (Veblen, 1908a,b,c).

\subsection{Capital as a potential resource}

What regards capital as a 'potential resource', note that 'Prospective' presupposes that a capital is durable, that is, transferable through history in things (objectified form) or in human beings (incorporated form), at a higher or lesser risk of being destroyed. Note also that the PPs and the $\mathrm{E}$ (cultural Embeddedness) have an important impact on the degree to which a capital is valued and becomes the object of human investments. Finally, the S (Strategic) should be seen as the 
sum of human agency to store up capital for future use, involving strategies of investment, future capitalization and maintenance (as capital depreciates over time).

As mentioned above, the definition of capital as PIPES is in many ways in line with both Veblen's (1908a,b,c) and Bourdieu's (1986) extended definitions of capital, comprising intangible assets.

Combining the findings of Marx, Veblen, Bourdieu, Lin and Light we suggest that capital is accumulated labor, stored in things or human beings, which is Productive and Interchangeable in the here and now (actual resource), and Prospective, Embedded and Strategic (potential resource).

Following this definition, social capital appears to be capital, in line with the traditional forms of capital. Thus, like physical, economic or human capital we can immediately profit from a social capital, e.g. in the form of information or help from friends. We can convert social capital into other forms of capital, e.g. get a better and more well-paid job. We can also 'cultivate' social capital in the hope of future profits, applying strategies modified by cultural codes.

However, in regard to ownership, social capital appears different from the other forms of capital. Thus, in contrast to other forms of capital, it is prevailingly a non-excludable good. This leads to a discussion of some of the criticisms that have been leveled on social capital as presented previously in this paper.

Vis-à-vis causality, it is possible to understand the cause and effect of social capital by understanding the above-mentioned interaction between actual and potential social capital. Since the benefits of investing in social capital are not necessarily immediately capitalizable, it is both possible and necessary to understand that there is an internal 'cause and effect' within social capital as it shifts from being an actual into being a potential resource.

This transcends to the issues of measuring social capital, since it is clear that regardless of the level of analysis, social capital cannot be measured as a one-dimensional construct. Looking at the downside of social capital, both negative externalities and the time perspective of social capital in the concept of investment and delayed benefits are framed much clearer.

\section{Case}

The following case from Scandinavia illustrates that the distinction between actual and potential social capital is not solely theoretical, but a very real one-albeit often implicit and vaguely defined. Not least, this is the case in many private organizations.

The Nordic Branch of a large international bank was facing a new market situation caused by European deregulation of capital markets. Therefore, the bank's previously very successful business model had to be reinvented, work processes realigned, and a large-scale organizational reshuffling was inevitable.

In order to make sense of the current interpersonal communication and collaboration patterns within and between departments, they asked one of the authors of this paper to perform an organization-wide social network analysis in the fall of 2005. When presenting the heads of departments with the results of the social network analysis, they were asked to name the reasons for seeking more collaboration with other departments, and about the biggest barriers for initiating and developing those relations.

The results of the analysis and the follow-up interviews with key individuals throughout the organization illustrated a clear division between the dense daily work-related networks, which were solely driven by task-solving performance, and the sparse network with colleagues in other departments, which had a longer time perspective and a more strategic focus. This is a very common structural property of such a network, which is well described and analyzed in the 
social networks literature, e.g. Hansen (1999), Tsai (2002) and is akin to the bridging-bonding characterization within the social capital literature \{Patulny, Forthcoming \#1281\}.

What became apparent was that the sparse inter-department networks were maintained primarily under the assumption that they might yield new business deals if the opportunities should arise. Thus, employees turned out to be extremely conscious of the dual build-up of both productive and prospective social capital, and of the very separate nature of the two types of capital. As one respondent put it:

"[The obstacles are due to] several strategic, tactical and operational reasons relating to differences between business models and phases, desires, motivation and incentives. It is not the access itself that would add value but it may give possibilities to do so."

However, the organization-wide changes taking place in the organization were already affecting the mindset of the employees, and at the time of the interviews there was a new sense of legitimacy in the conversion of potential to actual social capital: it was openly accepted that the goal was to create and develop new business opportunities. Consequently, the interviews revealed a new acknowledgement of the necessity of the interchangeability of human and social capital, as well as of the strategic advantages of accumulating and converting different types of networks (Coleman, 1988).

The process of analyzing the social capital embedded in the organizational networks revealed the role of network structures in both the short and long term on the micro level (inter-personal relations). Prior to the analysis there was a lack of understanding of how the benefits of the prospective capital could be understood in terms of potential social capital at the meso (organizational) level.

Some of that prospective capital was embedded in the weak ties to a number of specialists, typically senior bankers. The other employees' ties to these persons were weak, simply because they were generally hard to reach, but all the more important to both individual and organizational performance. The solution in this case was not to hire more senior bankers, but to understand that the resource that needed to be exchanged in the network was of a highly complex nature and culturally embedded. Therefore, the critical step for the organization was to mobilize a cultural change in the strategic use of the embedded social capital in order to facilitate a timely and open access to the resources embedded in the structural properties of the specialists. This was pointed out by several respondents and can be summed up in the following statement:

"We would like more access as we are too dependent on one single person in [HQ]. We would like more than one contact, so we could get more consistent and reliable support. This is the main obstacle: Getting from one key person to the whole system."

This shows another interesting aspect of the interchangeability between actual and potential social capital: the question about ownership of social capital. Thus, this case indicates that when social capital becomes too embedded in an organization, there is a clear risk that individual actors do not realize the potential benefit for them in converting the embedded resource to a more productive resource. As stated by the one head of department:

"Departments in HSH Nordbank do not at the same time require each other on a daily basis. We are like planets in the Universe who from time to time hit each other if 'required!'. Otherwise we exist independently from each other."

This shows us that there is a need for a more complex understanding of social capital than the traditional bridging/bonding (or brokerage and closure, Burt, 2005). By understanding the 
different mechanisms involved in converting potential capital into actual capital, and uncovering the hidden or implicit barriers therein, the concept of social capital can become a more precise and effective description of the resources embedded in social structures. It also gives an indication of the complexities involved in both understanding and operationalizing social capital within the PIPES framework. As our case clearly illustrates, this is due to the fact that there are no easy fixes or shortcuts for individuals or organizations seeking advice about how to get the best out of their actual and potential social capital. As summed up by one respondent:

"The obstacles are manifold: Discipline, missing teamwork, too many egocentric attitudes."

In this and similar cases we think that a PIPES model may allow for a much deeper understanding than previous models. This because it offers a more systematical and complex understanding of micro-level social capital within meso level contexts, by directing focus to the often forgotten aspects of social capital: interchangeability, embeddedness and strategy. However, we admit that our attempt is preliminary, and more theoretical and empirical research is needed.

\section{Conclusion}

First, in line with Bourdieu's (1977) original micro level oriented definition we argued that social capital consists of a sum of actual and potential resources for the individual. Here, actual social capital should be seen as the outcome of immediate capitalization of network resources. In contrast, potential social capital reflects long-term strategies, involving 'cultivation' of networks in complex cultural settings. We stressed that it is in fact the individual who accrues social and economic benefits from networking.

Second, we stressed that the individual actor strategically seeks to incalculate future capitalizations of networks. Such calculation is implicit in Bourdieu's (1977) early advocacy of an epistemological return 'from rules to strategies'. This implies recognition of actors' real strategies as characterized by structural unpredictability, in contrast to economists' economic rules of human behavior, which presupposes predictable and thus computable outcomes. Deeply rooted in important historical critiques of homo oeconomicus, our Bourdieu-inspired reframing of the social capital agenda takes into consideration the main critiques of social capital: problems with definition, causality, measurement, lack of a definition of a negative type of social capital, as well as distinguishing between micro and macro levels.

Second, maintaining that human strategies are reasonable (raissonables) rather than rational or cultural, as suggested by Bourdieu, involves an invitation to all social scientists to contribute to a truly cross-disciplinary neo-capital science. In a more fundamental way, our contribution here consisted in outlining a neo-capital theory that evaluates and links the traditional forms of capital with a contemporary 'plethora of capitals' (Woolcock, 1998, p. 155). We argued that such reorientation in the long run might lead to a new socioeconomics operating with both visible and invisible forms of capital at the same level in the analysis, thus bridging the gap between economic and socio-cultural studies. To honor Bourdieu, we termed this new science Bourdieuconomics. This lead to an outline of a concrete tool for a Bourdieuconomics-namely a capital test model, PIPES, based on an actual/potential resource perspective. The purpose was to unite classical and neo-capital theories by defining 'capital' as Productive, Interchangeable, Prospective, Embedded and Strategic.

Finally, within the PIPES framework, we described empirically the interchangeability of actual/potential social capital in a Scandinavian case. A key finding here was that actors in this private organization (a bank) in fact do make their social investment decisions out from what 
we here termed actual/potential social capital strategies. However, lack of access to key persons within the organization, as well as a general lack of information about how best to capitalize social networks seemed to be a barrier for single careers. Most probably, such barriers also lowered organizational and economic performance in general. In this way, our case suggests that a Bourdieusian inspired actual/potential definition can help us overcome some of the social capital 'childhood diseases', because it opens for quantitative and qualitative measurement of various types of social capital at micro and meso levels.

The concept of social capital appears fascinating, promising and problematic. It is our conviction that learning from Bourdieu's seminal ideas - implying distinction between actual/potential resources and operating with tangible/less tangible forms of capital - can help resolve some of the problems involved and thus enhance future exploitation of this concept.

\section{References}

Adler, P., Kwon, S.-W., 2002. Social capital: prospects for a new concept. Academy of Management Journal 27 (1), 17-40.

Anheier, H.K., Gerhards, J., Romo, F.P., 1995. Forms of capital and social structure in cultural fields: examining bourdieu's social topography. American Journal of Sociology 100 (4), 859-903.

Arrow, K.J., 2000. Observations on social capital. In: Dasgupta, P. (Ed.), Social Capital: A Multifaceted Perspective. The World Bank, Herndon, pp. 3-5.

Backhouse, R.E., 1998. If mathematics is informal, then perhaps we should accept that economics must be informal too. The Economic Journal 108, 1848-1858.

Banfield, E.C., 1958. The Moral Basis of a Backward Society. Free Press, New York.

Baron, J.N., Hannan, M.T., 1994. The impact of economics on contemporary sociology. Journal of Economic Literature 32 (3), 1111-1146.

Becker, G.S., 1964. Human Capital. Columbia University Press, New York, London.

Beugelsdijk, S., Smulders, S., 2004. Social Capital and Economic Growth.

Bolino, M.C., Bloodgood, J.M., Turnley, W.H., 2002. Organizational citizenship behavior and the creation of social capital in organizations. Academy of Management Review 27 (4), 505-522.

Borgatti, S.P., 1998. A SOCNET discussion on the origins of the term social capital. Connections 21 (2), 46.

Borgatti, S.P., Foster, P.B., 2003. The network paradigm in organizational research: a review and typology. Journal of Management 29 (6), 991-1013.

Bourdieu, P., 1977. Outline of a Theory of Practice. Cambridge University Press, Cambridge.

Bourdieu, P., 1979. Les trois états du capital culturel. Actes de la Recherche en Sciences Sociales 31, 3-6.

Bourdieu, P., 1980. Le capital social. Notes provisoires. Actes de la Recherche en Sciences Sociales 31, 2-3.

Bourdieu, P., 1986. The forms of capital. In: Richardson, J.G. (Ed.), Handbook of Theory and Research for the Sociology of Education. Greenwood Press, New York, pp. 241-258.

Bourdieu, P., 1989. Distinction: A Social Critique of the Judgement of Taste. Routledge, London.

Bourdieu, P., 1997. Le Champ Économique. Actes de la Recherche en Sciences Sociales 119, 48-66.

Bourdieu, P., 2000. Les Structures Sociales de L'économie. Seuil, Paris.

Brass, D.J., Labianca, G., 1999. Social capital, social liabilities, and social resources management. In: Leenders, R.T.A.J., Gabbay, S.M. (Eds.), Corporate Social Capital and Liability. Kluwer Academic Publishers, Amsterdam, pp. 323-340.

Bryden, J., Munro, G., 2000. New approaches to economic development in peripheral rural regions. Scottish Geographical Journal $116(2), 111-124$.

Burt, R.S., 1992. Structural Holes-The Social Structure of Competition. Harvard University Press, Cambridge, Massachusetts.

Burt, R.S., 2005. Brokerage \& Closure: An Introduction to Social Capital. Oxford University Press, Oxford.

Carley, K.M., Krackhardt, D., 1996. Cognitive inconsistencies and non-symmetric friendship. Social Networks 18 (1), $1-27$.

Chick, V., 1998. On knowing one's place: the role of formalism in economics. The Economic Journal 108, 1859-1869.

Chloupkova, J., Svendsen, G.L.H., Svendsen, G.T., 2003. Building and destroying social capital: the case of cooperative movements in Denmark and Poland. Agriculture and Human Values 20 (3), 241-252.

Coleman, J.S., 1988. Social capital in the creation of human capital. American Journal of Sociology 94, 95-121.

Coleman, J.S., 1990. Foundations of Social Theory. The Belknap Press of Harvard University Press, Cambridge, Massachusetts. 
Cornes, R., Sandler, T., 1986. The Theory of Externalities, Public Goods and Club Goods. Cambridge University Press, Cambridge.

Douglas, M., 1966. Purity and Danger. Penguin Books, Baltimore.

Durkheim, E., 1908, Débat sur l'économie politique et les sciences sociales, electronic version by Jean-Marie Tremblay: pages.infinit.nct/sociojmt, March 27, 2002.

Granovetter, M., 1985. Economic action and social structure: the problem of embeddedness. American Journal of Sociology 91 (3), 481-510.

Granovetter, M.S., 1973. The strength of weak ties. American Journal of Sociology 78 (6), 1360-1380.

Halpern, D., 2005. Social Capital, Polity.

Hanifan, L.J., 1916. The rural school community center. Annals of the American Academy of Political and Social Science 67, 130-138.

Hannertz, U., 1969. Soulside: Inquiries into Ghetto Culture and Community. Columbia University Press, New York.

Hansen, M.T., 1999. The search-transfer problem: the role of weak ties in sharing knowledge across organization subunits. Administrative Science Quarterly, 82-111.

Herreros, F., 2004. The Problem of Forming Social Capital: Why Trust? Houndmills, Palgrave Macmillan, New York.

Ibarra, H., 1992. Homophily and differential returns: sex differences in network structure and access in an advertising firm. Administrative Science Quarterly 37 (3), 422-447.

Johnson, J.C., Orbach, M.K., 2002. Perceiving the political landscape: ego biases in cognitive political networks. Social Networks 24 (3), 291-310, 2002/7.

Kadushin, C., 2004. Too much investment in social capital? Social Networks 26, 75-90.

Kapferer, B., 1988. Legends of People, Myths of State. Violence, Intolerance and Political Culture in Sri Lanka and Australia. Smithsonian Institution Press, Washington and London.

Keesing, R., 1992. Custom and Confrontation. Chicago University Press, Chicago.

Krackhardt, D., 1987. Cognitive social structures. Social Networks 9 (2), 109-134.

Krackhardt, D., 1990. Assessing the political landscape: structure, cognition and power in organizations. Administrative Science Quarterly 35 (2), 342-370.

Krugman, P., 1998. Two cheers for formalism. The Economic Journal 108, 1829-1836.

Labianca, G., Brass, D.J., Gray, B., 1998. Social networks and perceptions of intergroup conflict: the role of negative relationships and third parties. Academy of Management Journal 41 (1), 55-67.

Lazarsfeld, P.F., Merton, R.K., 1954. Friendship as social process: a substantive and methodological analysis. In: Berger, M., Abel, T., Page, C. (Eds.), Freedom and Control in Modern Society. Octagon, New York, pp. 18-66.

Leana, C.R., Van Buren, H.J., 1999. Organizational social capital and employment practices. Academy of Management Review 24 (3), 538-555.

Lebaron, F., 2003. Pierre Bourdieu: economic models against economism. Theory and Society 32 (5/6), 551-565.

Leenders, R.T.A.J., Gabbay, S.M. (Eds.), 1999. Corporate Social Capital and Liability. Kluwer Academic Publishers, Amsterdam.

Lesser, E.L., 2000. Leveraging social capital in organizations. In: Lesser, E.L. (Ed.), Knowledge and Social Capital-Foundations and Applications. Butterworth Heinemann, Boston.

Light, I., 2001. Social capital's unique accessibility. In: Paper Presented at the The Danish Building and Urban Research/EURA, Copenhagen, 17-19 May.

Lin, N., 1999. Building a network theory of social capital. Connections 22 (1), $28-51$.

Lin, N., 2001. Social Capital: A Theory of Social Structure and Action. Cambridge University Press, New York.

Mahar, C., Harker, R., Wilkes, C., 1991. The basic theoretical position. In: Harker, R., Mahar, C., Wilkes, C. (Eds.), An Introduction to the Work of Pierre Bourdieu. The Practice of Theory. Macmillan, London, pp. 1-25.

Marx, K., 1995. Capital: A New Abridgement. Oxford University Press, New York.

McPherson, M., Smith-Lovin, L., Cook, J.M., 2001. Birds of a feather: homophily in social networks. Annual Review of Sociology 27, 415-444.

Mingione, E., 1991. Fragmented Societies: A Sociology of Economic Life Beyond the Market Paradigm. Basil Blackwell, Oxford.

Nahapiet, J., Ghoshal, S., 1998. Social capital, intellectual capital, and the organizational advantage. Academy of Management Review 23 (2), 242-266.

Paldam, M., Svendsen, G.T., 2000. An essay on social capital: looking for the fire behind the smoke. European Journal of Political Economy 16 (2), 339-366, 2000/6.

Patulny, R., 2003. From family to fellowship: defining multiple forms of bonding social capital and pathways through values and time use analysis. In: Paper Presented at the Australian Social Policy Conference, Sydney.

Polanyi, K., Arensberg, C., Pearson, H., 1957. Trade and Markets in the Early Empires. Free Press, New York. 
Pollitt, M., 2002. The economics of trust, norms and networks. Business Ethics: A European Review 11 (2), 119-128. Portes, A., 1998. Social capital: its origins and applications in modern sociology. Annual Review of Sociology 24, 1-24. Portes, A., 2000. The two meanings of social capital. Sociological Forum 15 (1), 1-12.

Portes, A., Landolt, P., 1996. Unsolved mysteries: the tocqueville files II-the downside of social capital. The American Prospect 7 (26), 18-21.

Putnam, R.D., 1993. Making Democracy Work. Civic Traditions in Modern Italy. Princeton University Press, Princeton.

Putnam, R.D., 1995. Tuning in, tuning out: the strange disappearance of social capital in America. PS: Political Science and Politics 28 (4), 664-683.

Putnam, R.D., 1996. The strange disappearance of civic America. The American Prospect 24, 34-48.

Putnam, R.D., 2000. Bowling Alone-The Collapse and Revival of American Community. Simon \& Schuster, New York.

Roberts, J.M., 2004. What's 'Social' about 'Social Capital'? British Journal of Politics and International Relations 6 (4), 471-493.

Robison, L.J., 1996. In Search of Social Capital in Economics.

Robison, L.J., Schmid, A.A., Siles, M.E., 2002. Is social capital really capital? Review of Social Economy 60 (1), 1-20.

Schudson, M., 1996. What if civic life didn't die? The American Prospect 25, 17-20.

Schultz, T.W., 1961. Investment in human capital. American Economic Review 51 (1), 1-17.

Skocpol, T., 1996. Unravelling from above. The American Prospect 25, 20-24.

Smith, A., 1976. The wealth of nations. In: An Inquiry into the Nature and Causes of the Wealth of Nations. Clarendon Press, Oxford.

Solow, R.M., 2000. Notes on social capital and economic performance. In: Dasgupta, P., Serageldin, I. (Eds.), Social Capital: A Multifaceted Perspective. World Bank, Washington, DC, pp. 6-10.

Svendsen, G.L.H., 2006. Studying social capital in situ. An anthropological approach. Theory and Society 35 (1), 39-70.

Svendsen, G.L.H., Svendsen, G.T., 2003. On the wealth of nations: Bourdieuconomics and social capital. Theory and Society 32 (5-6), 607-631.

Svendsen, G.L.H., Svendsen, G.T., 2004. The creation and destruction of social capital: entrepreneurship. In: Co-operative Movements and Institutions. Edward Elgar, Cheltenham, UK, Northampton, MA, USA.

Tambiah, S.J., 1996. Leveling Crowds. Ethnonationalist Conflicts and Collective Violence in South Asia. University of California Press, Berkeley, Los Angeles, London.

Tsai, W., 2002. Social structure of 'coopetition' within a multiunit organization: coordination, competition, and intraorganizational knowledge sharing. Organization Science: A Journal of the Institute of Management Sciences 13 (2), 179-190.

Turner, V., 1967. The Forest of Symbols. Cornell University Press, Ithaca, New York.

Täube, V.G., 2004. Measuring the social capital of brokerage roles. Connections 26 (1), 29-52.

Uslaner, E., 2002. The Moral Foundations of Trust. Cambridge University Press, New York.

Veblen, T., 1908a. Fisher's capital and income. Political Science Quarterly 23 (1), 112-128.

Veblen, T., 1908b. On the nature of capital. The Quarterly Journal of Economics 22 (4), 517-542.

Veblen, T., 1908c. On the nature of capital: investment, intangible assets, and the pecuniary magnate. The Quarterly Journal of Economics 23 (1), 104-136.

Waldstrøm, C., 2003. Social Capital in Organizations-Beyond Structure and Metaphor.

Weintraub, R.E., 1998. Controversy: axiomatisches Missverständnis. The Economic Journal 108, 1837-1847.

Woolcock, M., 1998. Social capital and economic development: toward a theoretical synthesis and policy framework. Theory and Society 27 (2), 151-208. 